Наливайко Т. Е., Ворончихина Е. Ю.

АКТУАЛИЗАЦИЯ ФОРМИРОВАНИЯ КОММУНИКАТИВНОЙ КОМПЕТЕНТНОСТИ БАКАЛАВРОВ НАПРАВЛЕНИЯ ПОДГОТОВКИ

«ГОСУДАРСТВЕННОЕ И МУНИЦИПАЛЬНОЕ УПРАВЛЕНИЕ»

Наливайко Т. Е., Ворончихина Е. Ю.

T. Ye. Nalivaiko, E. Yu. Voronchikhina

АКТУАЛИЗАЦИЯ ФОРМИРОВАНИЯ КОММУНИКАТИВНОЙ КОМПЕТЕНТНОСТИ

БАКАЛАВРОВ НАПРАВЛЕНИЯ ПОДГОТОВКИ «ГОСУДАРСТВЕННОЕ

И МУНИЦИПАЛЬНОЕ УПРАВЛЕНИЕ»

\title{
COMMUNICATIVE COMPETENCE FORMATION OF BACHELORS MAJOR IN STATE AND MUNICIPAL MANAGEMENT
}

Наливайко Татьяна Евгеньевна - доктор педагогических наук, профессор, проректор по учебновоспитательной работе Комсомольского-на-Амуре государственного технического университета (Россия, Комсомольск-на-Амуре); 681013, г. Комсомольск-на-Амуре, ул. Ленина, д. 27, 8-4217-53-98-25. E-mail: tenal@knastu.ru

Ms. Tatiana Ye. Nalivaiko - Doctor in Education, Professor, Vice-rector for Educational Work, Komsomolsk-onAmur State Technical University (Russia, Komsomolsk-on-Amur); 27 Lenin Str., Komsomolsk-on-Amur, zip code 681013, tel. 8-4217-53-98-25. E-mail: tenal@knastu.ru.

Ворончихина Елена Юрьевна - аспирант Комсомольского-на-Амуре государственного технического университета. E-mail: missislena@mail.ru

Ms. Elena Yu. Voronchikhina - Post-graduate student, Komsomolsk-on-Amur State Technical University. E-mail: missislena@mail.ru

Аннотация. Статья посвящена актуальной проблеме современной педагогики - совершенствованию подготовки бакалавра технического вуза в условиях перехода высшей школы на новое поколение стандартов высшего профессионального образования. Рассматривается коммуникативная компетентность - одна из наиболее важных составляющих профессиональной подготовки государственных и муниципальных служащих. Подчеркивается необходимость корректирования системы подготовки бакалавров, создания модели формирования коммуникативных компетенций.

Summary. The article is devoted to a vital problem of modern Pedagogy that is to improve bachelor training in technical universities in conditions of new standards of higher education. The authors study the communicative competence that is one of the most important components of professional training of public service employees, and point to the need of adjusting the system of bachelor training, as well as creating a model of communicative competence.

Ключевые слова: коммуникативная компетентность; профессиональная коммуникация; коммуникативная деятельность; государственный служащий; государственное и муниципальное управление; бакалавры.

Key words: communicative competence; professional communication; communicative activity; public service employee; state and municipal management; bachelors.

УДК 378

Одной из основных тенденций современного развития общества является повышение требований к уровню профессиональной подготовки выпускников высших учебных заведений. Перевод отечественного образования на новое поколение федеральных стандартов требует от высшей профессиональной школы пересмотра принципов и методов обучения и воспитания бакалавра, а введение профессиональных стандартов определяет горизонты для подготовки выпускника вуза как профессионала, владеющего не только знаниями, умениями и навыками, но и прошедшего школу профессиональной социализации, построенную на коммуникативном взаимодействии со всеми аспектами профессиональной деятельности. 
Обучение коммуникативной деятельности является одной из доминант высшего образования, и в связи с этим перед педагогической наукой стоят новые задачи, заключающиеся, прежде всего, в создании концепции формирования коммуникативной компетентности у будущих бакалавров.

Развитие коммуникативной компетентности бакалавров, обучающихся по направлению подготовки «Государственное и муниципальное управление», является сегодня одной из ключевых образовательных задач их профессиональной подготовки. Указанной проблеме посвящены работы Ю.В. Рождественского, И.А. Стернина, Н.Н. Еговцевой, О.А. Астафьевой, Л.Д. Чайновой, Е.А. Запорожец и др.

На сегодняшний день в науке существует множество определений «коммуникативной компетентности». Проанализировав существующие исследования по данной проблеме, мы можем выделить два основных подхода, существующих в педагогической науке, относительно понимания сущности коммуникативной компетентности. Представители первого подхода в понимание процесса развития коммуникативной компетентности включают формирование знаний, умений и навыков общения. Представители второго подхода, помимо познавательного аспекта, - создание комплексного единства эмоционально-волевого и мотивационно-ценностного компонентов в личности выпускника высшей школы.

По мнению авторов данной статьи, под коммуникативной компетентностью бакалавра понимается приобретаемый в процессе обучения и воспитания комплекс личностных и профессиональных качеств, основанных на получении знаний, умений, навыков в области коммуникации и успешно применяемых в профессиональной деятельности и межличностных взаимоотношениях, способствующий профессиональному и личностному росту бакалавра.

Говоря о требованиях к коммуникативным способностям выпускника направления «Государственное и муниципальное управление», необходимо отметить, что они напрямую должны коррелировать с профессиональными требованиями, предъявляемыми к муниципальным и государственным служащим. Государственный служащий - это, прежде всего, государственный управленец, менеджер-чиновник, это человек, олицетворяющий власть и выступающий от ее лица, следовательно, он должен обладать высоким уровнем сформированности коммуникативной компетентности, так как на нём лежит колоссальная ответственность за профессиональное общение и его последствия.

Государственная и муниципальная служба является областью повышенной коммуникативной ответственности. Неправильная интерпретация устного и письменного распоряжения может привести к серьёзным последствиям в управлении, стать причиной недоразумений и конфликтов, различного рода ошибок в принятии решений.

Госслужащий является публичным лицом, поэтому должен обладать высоким уровнем коммуникативной культуры, уметь общаться и находить язык с широким кругом лиц, владеть различными приёмами как непосредственного, так и опосредованного общения с аудиторией. У него должны быть сформированы умения и навыки в области профессиональной коммуникации, которые помогут обеспечить высокую результативность и эффективность решения различного рода проблем, возникающих в ходе производственной и управленческой деятельности, а также помогут устанавливать успешные межличностные и договорные отношения в сфере государственного и муниципального регулирования.

Важно отметить, что профессиональное взаимодействие в отрасли государственного и муниципального управления представлено несколькими сегментами коммуникативной интеракции: между начальником и руководителем, между рядовыми сотрудниками; между государственными служащими и населением; между социальными институтами, службами, подразделениями. Эффективность принятия управленческих решений во многом зависит от того, насколько государственный или муниципальный служащий сумеет квалифицированно и конструктивно организовать коммуникационное взаимодействие в каждом из вышеобозначенных сегментов.

В ходе профессиональной деятельности госслужащему приходится не только заниматься нормотворчеством, интерпретировать документы и руководствоваться должностными инструкци- 
Наливайко Т. Е., Ворончихина Е. Ю.

АКТУАЛИЗАЦИЯ ФОРМИРОВАНИЯ КОММУНИКАТИВНОЙ КОМПЕТЕНТНОСТИ БАКАЛАВРОВ НАПРАВЛЕНИЯ ПОДГОТОВКИ «ГОСУДАРСТВЕННОЕ И МУНИЦИПАЛЬНОЕ УПРАВЛЕНИЕ»

ями, но и разъяснять и доказывать свою позицию, убеждать и переубеждать участников коммуникации, формировать общественное мнение. Сотрудник администрации любого уровня постоянно решает различные социальные, хозяйственные и личные проблемы граждан; общается с людьми, принадлежащими к различным социальным слоям и группам; контактирует с представителями разных общественно-политических взглядов и убеждений.

Бакалавр, обучавшийся по направлению «Государственное и муниципальное управление», должен стать «профессиональным коммуникатором», обладать высоким уровнем сформированности коммуникативной компетентности. Его подготовленность к решению профессиональных задач влияет не только на его личную репутацию, но и формирует имидж того учреждения, которое он представляет.

Для выявления степени подготовленности бакалавров направления подготовки «Государственное и муниципальное управление» в течение 2015-2016 учебного года среди студентов выпускных курсов, обучавшихся по данному направлению, нами было проведено исследование, позволившее определить уровень сформированности коммуникативной компетентности, коммуникативных и организаторских склонностей и способностей. В исследовании использовались следующие методики: «Диагностика коммуникативных и организаторских склонностей» (КОС-2); «Диагностика общей коммуникативной толерантности», предложенная В.В. Бойко, «Диагностика коммуникативного контроля» М. Шнайдера и тест по культуре речи.

Как показало проведённое нами исследование, значительная часть будущих бакалавров имеет недостаточный уровень сформированности коммуникативной компетентности, что может привести впоследствии к проблемам с их трудоустройством и с эффективным выполнением ими своих должностных обязанностей.

Отсюда следует, что в процессе развития коммуникативной компетенции основной целью образовательного процесса является формирование личных и профессиональных коммуникативных качеств будущих государственных и муниципальных служащих и наполнение их соответствующими умениями и навыками, необходимыми для эффективного профессионального общения. Для того чтобы успешно реализовать данную цель, необходимо обеспечить выполнение ряда условий.

Развитие коммуникативных качеств у бакалавров происходит в ходе освоения теоретических знаний и практических умений и навыков. На теоретическом уровне студент изучает суть и специфику профессионального общения, характерного для государственной и муниципальной службы. Изучает правила и стили общения, усваивает необходимый набор знаний в области психологии и педагогики общения, анализирует наиболее распространенные случаи деловой и повседневной коммуникации и т.д. Практический уровень обучения предусматривает освоение и использование в обыденной и профессиональной деятельности умений и навыков коммуникации в различных социальных условиях.

При этом преподавателю необходимо делать упор на развитие знаний, умений и навыков, прежде всего, межличностного общения, т.е. в процессе преподавания различных дисциплин студент и педагог должны постоянно общаться, вести диалог, спорить, беседовать, что позволит, на наш взгляд, создать условия развития коммуникативной компетенции. На каждой дисциплине, особенно предметах психолого-педагогического и гуманитарного цикла, студент должен осваивать различные аспекты коммуникативного взаимодействия, нормы этики профессионального общения, приемы презентации идей и самопрезентации, учиться грамотному общению с аудиторией.

В программы учебных дисциплин и планы занятий необходимо включать темы и задания, направленные на освоение и выполнение риторических действий. Студент должен постоянно пребывать в непрерывном процессе коммуникации. Причем данный процесс должен носить интерактивный характер, то есть необходимо использовать различные способы и системы коммуникативного взаимодействия.

В этой связи мы считаем необходимым использование, прежде всего, интерактивных методов обучения. Интеракция позволит студенту освоить широкий спектр способов эффективной коммуникации, основанной на знаниях психологии, социологии и этики. Она сформирует навыки 
неординарного мышления при решении проблемных ситуаций; научит правилам ведения дискуссии и спора, соблюдать принципы толерантности, доброжелательности и плюрализма мнений.

Основным наиболее эффективным методом в этом смысле нам видится «коммуникативная игра». Данный метод предполагает организацию коммуникативного взаимодействия, максимально приближенного к условиям реального процесса общения на производстве. Например, в сотрудничестве преподавателя и студента могут быть заложены примеры будущего взаимодействия руководителя и подчиненного.

Коммуникативная игра является, по сути, одной из разновидностей деловых игр. С той лишь разницей, что коммуникативная игра выполняет лишь риторическую функцию интерактивного взаимодействия, а деловая игра предусматривает весь комплекс деятельности, имеющий цель смоделировать реальную ситуации, с которой будущий бакалавр может столкнуться на работе. Использование данного метода позволит будущим административным работникам освоить различные профессиональные функции и подготовиться к специфике взаимоотношений, господствующих в среде государственных и муниципальных служащих.

Кроме игр считаем, что целесообразно использовать в ходе обучения психологические групповые тренинги, способствующие повышению уровня коммуникативной подготовленности будущих государственных и муниципальных служащих, преодолению трудностей в общении, формированию коммуникативных способностей, необходимых в их профессиональной деятельности.

Тренинг общения способствует эффективному формированию и развитию техник общения, он позволяет разобрать и подготовиться к основным коммуникативным ситуациям, с которыми у служащего могут возникнуть трудности.

Кроме активных методов обучения вполне допустимы и пассивные дидактические системы. Например, очень эффективным для развития коммуникативных способностей является аналитическое наблюдение коммуникативного взаимодействия как реального, так и представленного в художественной форме. Оно дает не только возможность «тренировки» приобретенных познавательных средств, но и способствует овладению средствами регуляции собственного коммуникативного поведения. В частности, процесс наблюдения позволяет выявить систему правил, руководствуясь которыми, специалисты государственной или муниципальной службы организуют свое взаимодействие, понимают, какие правила способствуют, а какие - препятствуют успешному протеканию коммуникативных процессов. Не случайно наблюдение за коммуникативным поведением других людей рекомендуется в качестве эффективного способа повышения собственной компетентности.

Важным моментом процесса формирования коммуникативных навыков у государственных служащих является мысленное проигрывание своего поведения в различных ситуациях. Планирование своих действий «в уме» является составной частью нормально протекающего коммуникативного действия. Способность человека действовать «в уме» может быть целенаправленно использована для обеспечения «контролируемой спонтанности», являющейся важной характеристикой компетентного коммуникативного поведения [4].

Кроме указанной коммуникативной направленности различных дисциплин необходимо ввести в учебный план профессиональной подготовки государственных и муниципальных служащих дисциплины по выбору, такие как: «Основы профессионального общения», «Речевая культура государственного и муниципального служащего», «Управление коммуникациями», при изучении которых студенты усваивают навыки профессионального, грамотного, эффективного общения.

Данные курсы, во-первых, помогут студентам обобщить, систематизировать знания по вопросам общения, усвоенные ранее, получить новую информацию и более глубокие знания в области профессионального общения. Во-вторых, будут способствовать интенсивному развитию коммуникативных, в том числе профессиональных, качеств будущего госслужащего, его коммуникативных умений и навыков, раскрытию его коммуникативного потенциала. Цель указанных дисциплин - повысить уровень коммуникативной компетентности госслужащих, что, в свою очередь, является необходимым условием эффективности государственного управления. 
Наливайко Т. Е., Ворончихина Е. Ю.

АКТУАЛИЗАЦИЯ ФОРМИРОВАНИЯ КОММУНИКАТИВНОЙ КОМПЕТЕНТНОСТИ БАКАЛАВРОВ НАПРАВЛЕНИЯ ПОДГОТОВКИ

«ГОСУДАРСТВЕННОЕ И МУНИЦИПАЛЬНОЕ УПРАВЛЕНИЕ»

Несомненно, ведущую роль в образовательном процессе играет преподаватель. Он должен являть собой эталон профессионального общения, деловой коммуникации. Студент находится в той системе координат, которую ему задает педагог, поэтому от его профессионализма и отношения к своей профессии зависит успешность профессиональной социализации будущего бакалавра.

Преподаватель является, с одной стороны, образцом коммуникативной деятельности профессиональной деятельности, а с другой стороны, он является организатором процесса формирования профессиональных качеств будущих государственных и муниципальных служащих, что повышает требования к уровню профессиональных и личностных качеств самого преподавателя.

В качестве вывода следует отметить следующее. Профессиональная деятельность государственных и муниципальных служащих носит, прежде всего, коммуникативный характер и, следовательно, важнейшей составляющей профессионального образования бакалавров направления подготовки «Государственное и муниципальное управление» является формирование высокого уровня коммуникативной компетентности. Подготовка квалифицированного государственного или муниципального служащего должна быть направлена на развитие способностей к межличностному общению, умений использовать различные средства коммуникации, причем не только языковой, в различных социальных ситуациях.

Для решения данных дидактических задач необходимо скорректировать систему подготовки бакалавров, создать модель формирования коммуникативных компетенций, перенеся акцент подготовки на развитие практических способностей эффективной коммуникации в сфере профессионального взаимодействия.

\section{ЛИТЕРАТУРА}

1. Богданова, Л. В. Коммуникационная компетентность как компонент профессионализма и конкурентоспособности будущих менеджеров / Л. В. Богданова // Ученые записки (РГСУ). - 2009. - № 9. - С. 121-126.

2. Ведмецкая, Л. В. Проблемы профессионального языка государственных служащих и развитие системы государственного управления / Л. В. Ведмецкая // Общие вопросы политических наук. - 2012. - № 1 .

3. Заливанский, Б. В. Формирование информационно-коммуникативных компетенций муниципальных служащих / Б. В. Заливанский // Гуманитарные научные исследования. - 2014. - № 9 [Электронный ресурс]. URL: http://human.snauka.ru/2014/09/7711 (дата обращения: 12.11.2015).

4. Запорожец, Е. А. Коммуникативная компетенция государственных служащих: структура, содержание, условия формирования / Е. А. Запорожец //Вопросы управления. - 2009. - № 3(8) сентябрь.

5. Наливайко, Т. Е. Понимание «коммуникативной компетентности» в контексте подготовки государственных и муниципальных служащих / Т. Е. Наливайко, Е. Ю. Ворончихина // Альманах мировой науки. 2016. - № 1-2(4). 